\title{
Obituary
}

\section{Mr. C. E. Stromeyer}

$\mathrm{H}^{4}$ ALF a century ago the practices used in the design and construction of industrial boilers left much to be desired in the way of scientific treatment, and it is no exaggeration to say that Charles Edmond Stromeyer, as chief engineer to the Manchester Steam Users' Association, was a leading spirit in the process of transforming the existing art into something approaching an exact science. The reason is not difficult to find, since he possessed an inborn capacity for investigation and research, to which was added the experience gained during seventeen years as an engineer surveyor to Lloyd's Register of Shipping. During that persistent endeavour, which occupied thirty years, the city of his adoption was a centre of interest for those engaged on the construction and maintenance of boilers, for engineers from distant lands frequently called upon him-and the pilgrimage continued after the year of retirement, in 1928. For this reason, a wide circle of friends must have welcomed the honorary degree of Dr. Ing. that was conferred last year by the Technische Hochschule at Aachen on its old graduate.

It is strange to recall that Stromeyer's apprenticeship was terminated due to an incapacity for further manual labour, since up to a few weeks before his death at Bad Nauheim, on July 23, in his eightieth year, he daily attacked the work that lay before him in the study and the laboratory. As a further indication of this unceasing activity of mind and body, it may be remarked that the manuscript of his "Unity in Nature", which may still be read with much pleasure and profit, was written en route during bi-weekly journeys between Manchester and London in the years preceding the War, when he was much occupied on professional and scientific affairs in London. Not the least important of those interests were matters connected with the foundation of the National Physical Laboratory.

Since he belonged to a generation that regarded education mainly as a training for independent thinking, Stromeyer's contributions to the proceedings of the Royal Society and our senior engineering and naval institutions almost invariably formed milestones by the way of progress in his sphere of interests. The ground included in that sphere was extensive, as he made the first direct determination of Poisson's ratio, used his interference strain indicator to measure the stresses on ships and the strains on railway bridges in the 'eighties, and contributed an instructive paper, on map-projection, to the International Geographical Congress held at Berlin in 1900. His work on the fatigue of metals is of outstanding merit, and the involved investigations doubtless gave rise to an original contribution presented in 1907 to the Manchester Literary and Philosophical Society, in which the atomic weights of the elements were expressed in the form of a harmonic series. In view of such a wide and deep knowledge of natural philosophy, it is in the nature of things that his "Marine Boiler Management and Construction" should have attained a sixth edition, apart from foreign translations of the volume.

With his intense devotion to work, anything short of transparent honesty met with Stromeyer's strongest disapproval, and he considered no weapon too heavy to handle in the defence of what appeared to be the right course of conduct. That characteristic must have served him well during the War period, in undertaking the exacting duty of examining and reporting on the safety of secondhand boilers that would not have been used in other circumstances.

To those who were privileged to know him intimately, Stromeyer's cultured and attractive outlook on life was a constant source of pleasure, as the labour of the day never seemed to tire the boyish spirit that was the deep-seated source of his activity. The welfare of his assistants was as real a concern to him as was their success in professional affairs, and they, along with many others, will place him in that small company of whom it may be said that they were "Servants upon horses, and princes walking as servants upon the earth". In that role his charming wife bore him faithful company. D. L-T.

\section{Dr. Arthur Bramley}

THE death of Dr. Arthur Bramley on July 19 deprives chemical and metallurgical science of a brilliant worker. Born in 1878, he was forced to leave school early, and served a full apprenticeship to the hosiery trade. He commenced his technical education in Halifax Technical College, and in 1904 obtained a staff appointment there. This was followed in 1906 by a national scholarship of the Royal College of Science where he graduated, carried out research work and finally became private research assistant to Prof. J. C. Philip. With the latter he conducted a number of researches on the physicochemical properties of solutions and ionic complexes the results of which are published in the Journal of the Chemical Society. He then proceeded to investigate the physical properties of binary liquid mixtures, for which work he was awarded the degree of D.Sc.

The second phase of Dr. Bramley's service to science commenced with his appointment to the technical staff of British Dyestuffs Corporation at Huddersfield, where he remained until he was appointed to take charge of the Department of Pure and Applied Science, Loughborough College, in 1918. At Loughborough he commenced a long series of researches on the diffusion of non-metallic elements into iron and steel and was able to show that the mechanism of this diffusion follows the normal physico-chemical course. These researches, published over a period of fifteen years, obtained for 